\title{
Initiation and perpetuation of rat adjuvant arthritis is inhibited by the anti-CD2 monoclonal antibody (mAb) OX34
}

Jörg C Hoffmann, Claudia Herklotz, Henning Zeidler, Bettina Bayer, Herbert Rosenthal, Jürgen Westermann

\begin{abstract}
Objective-The purpose of this study was to investigate the therapeutic potential of the anti-CD2 $\mathrm{mAb}$ OX34 first with regard to bone protection in established rat adjuvant arthritis (AA) and secondly with regard to prevention of $A A$ induction. Methods-Established AA was treated with dexamethasone (1 $\mathrm{mg} / \mathrm{kg}$ body weight) for two days plus OX34 mAb or control $\mathrm{mAb}$ over three days $(2 \mathrm{mg}$ and then $1 \mathrm{mg}$ ) starting at different time points of the disease. For prevention studies animals were injected as above with $\mathrm{mAb}$ before induction of AA. Arthritis score (AS), hindpaw thickness, and body weight were blindly measured three times per week. Flow cytometry and hindpaw radiography were performed at the end of the study (day 29).

Results-Treatment of early AA with OX34 mAb combined with dexamethasone but not dexamethasone plus control mAb dramatically suppressed established $A A$ as assessed by AS and hind paw thickness $(>65 \%$ and $>80 \%$ reduction, respectively; $p<0.05)$. Most importantly, early treatment in the course of AA almost completely prevented bone destruction in established AA. When given before AA induction OX34 alone prevented the initiation of arthritis compared with controls (AS reduction $83-95 \%, p<0.05$ ). In addition, OX34 plus dexamethasone treatment resulted in depletion of $\mathrm{CD}^{+} \mathrm{T}$ cells but not $\mathrm{CD}^{+} \mathrm{T}$ cells. IL2R ${ }^{+}$and $\mathrm{CD}^{-} 5 \mathrm{RC}^{-}$ ('memory') $T$ cells were significantly reduced.

Conclusions-Anti-CD2 mAb treatment prevents $A A$ induction confirming the role of $\mathrm{CD}^{+} \mathrm{T}$ cells in the induction phase of AA. In addition, early OX34 plus dexamethasone treatment resulted in pronounced clinical improvement and joint protection. OX34 treatment therefore inhibits the initiation and the perpetuation of rat AA.
\end{abstract}

(Ann Rheum Dis 1997;56:716-722)

Correspondence to: Dr J C Hoffmann, Innere Medizin II, Med Klinik und Poliklinik, Universität des Saarlandes, 66421 Homburg, Germany.

Accepted for publication 12 September 1997 adjuvant arthritis (AA) serves as an animal model for RA. Although the clinical course of
Rheumatoid arthritis (RA) is characterised by mononuclear cell infiltrates in the synovium
AA is somewhat different it shares important features with RA - that is, polysynovitis, characteristic histological findings, and ultimately erosive bone destruction. ${ }^{12}$ In addition, the clinical response to anti-inflammatory agents is similar in RA and established AA. Therefore, this model has been widely used for therapeutic and pathogenetic studies of chronic forms of arthritis. ${ }^{13-6}$

Currently available anti-rheumatic agents (that is, corticosteroids, non-steroidal antiinflammatory drugs (NSAIDs), and disease modifying anti-rheumatic drugs (DMARDs)) are known for their potent anti-inflammatory effectiveness. However, none of these drugs are able to stop joint destruction, although some DMARDs, particularly methotrexate and parenteral gold, have been shown to somewhat slow disease progression..$^{7-9}$ New therapeutic strategies for chronic forms of arthritis have to aim at both, suppression of inflammation and bone protection. To achieve these goals it is important to understand the different stages of disease progression and to identify relevant targets-that is, most relevant cell type(s) or cytokine(s), or both.

We previously reported on the antiinflammatory effects of an anti-CD2 mAb OX34 in established AA. ${ }^{10}$ This $\mathrm{mAb}$ was found to deplete transiently $\mathrm{CD}^{+}$but not $\mathrm{CD}^{+} \mathrm{T}$ cells. We now investigate whether treatment with OX34 has an influence on bone destruction as assessed by radiography and, in an attempt to further understand different phases of arthritis development, whether OX34 $\mathrm{mAb}$ treatment can prevent the induction of arthritis. Our data demonstrate that OX34 almost completely prevents AA development and, more importantly, when used with a corticosteroid pulse treatment effectively suppresses established AA leading to joint protection. Therefore, OX34 treatment interferes with the initiation and perpetuation of this chronic form of arthritis.

\section{Methods}

ANIMALS

Inbred female Lewis rats were obtained from the Abteilung Versuchstierkunde of the Medizinische Hochschule. The animals were kept under specified pathogen free conditions, were housed at two to three animals per cage, and fed standard rodent chow and water ad libitum. 
MAB, DEXAMETHASONE

The hybridoma cells producing mouse anti-rat $\mathrm{CD} 2 \mathrm{mAb}$ (OX34, IgG2a) were kindly provided by $\mathrm{A} N$ Barclay, University of Oxford, $\mathrm{UK}$, the mouse antihuman LFA-3 mAb AICD58.6 (IgG2a) was used as control $\mathrm{mAb}$ (a gift from S C Meuer, Heidelberg, Germany). Purified $\mathrm{mAb}$ was produced in spinner flask followed by affinity chromatography using protein A sepharose beads. Purified mAb were filtered $(0.25 \mu \mathrm{m})$ and administered intraperitoneally. OX34 was given at a loading dose of 2 $\mathrm{mg}$ followed by $1 \mathrm{mg}$ on the subsequent two days unless stated otherwise. Dexamethasone was diluted in phosphate buffered saline (PBS) giving a dose of $1 \mathrm{mg} / \mathrm{kg}$ body weight and injected intraperitoneally.

INDUCTION OF AA, CLINICAL AND RADIOGRAPHIC ASSESSEMENT

AA was induced by intradermal injection into the tail base with $0.1 \mathrm{ml}$ of FCA containing 10 $\mathrm{mg} / \mathrm{ml}$ Mycobacterium tuberculosis (R73Ra) diluted in incomplete Freund's adjuvant (both Difco Laboratories, Detroit, MI, USA). AA developed between day 10 and 15 . The severity of arthritis was evaluated by a blinded investigator (JCH or JW) three times per week on a scale of 0 to 4 per limb based on increasing swelling and periarticular erythema as previously described. ${ }^{10}$ The maximum arthritis score (AS) was therefore 16. At the same time the body weight was measured. Hindpaw thickness was measured as previously described using calipers. ${ }^{11}$ Established AA was arbitrarily defined as clear arthritis (AS per limb $\geqslant 1$ ) in at least two limbs (total $A S \geqslant 2$ ). Using these criteria $75 \%$ of all animals had established AA by day 12 and $100 \%$ by day 15 . At the end of the study the animals were killed and both hindlimbs were amputated, frozen at $-80^{\circ} \mathrm{C}$, and radiographed using mammography technique at $20 \mathrm{mAs}$. Radiographic scoring was performed by assessing soft tissue swelling, periosteal new bone formation, joint space narrowing, periarticular osteoporosis, and bone destruction on a scale of 0 (normal) to 3 (maximum) per hindlimb. ${ }^{12}$ Scoring was performed by two independent, blinded investigators ( $\mathrm{JCH}$ and $\mathrm{CH}$ ). The maximum radiographic score was 6 per animal.

SUBSET ANALYSIS OF BLOOD LYMPHOCYTES BY FLOW CYTOMETRY

Peripheral blood was obtained by venopuncture from the retro-orbital plexus. Numbers of leucocytes were determined in duplicate samples using a Coulter counter and three differential blood smears were prepared. Red blood cells were lysed using a hypotonic solution as previously described. ${ }^{13}$ Hybridoma cell lines were kindly provided by A N Barclay, University of Oxford, UK, and T Hünig, University of Würzburg, Germany. Double staining was performed using pairs of biotinylated or FITC conjugated mouse anti-rat $\mathrm{mAb}$ and streptavidin red 670 as secondary antibody giving the following lymphocyte subsets ${ }^{10}$ : $\mathrm{B}$ lymphocytes ( $\kappa$ light chain $\left.{ }^{+}, \mathrm{OX} 12\right), \mathrm{CD}^{+} \mathrm{T}$ cells $\left(\mathrm{W} 3 / 25^{\text {high }}\right) \mathrm{CD}^{+} \mathrm{T}$ cells $\left(\mathrm{R}^{+} 3^{+}, \mathrm{OX}^{+}\right)$, natural killer cells $\left(\mathrm{R}^{-} 3^{-}, \mathrm{OX}^{+}\right)$, monocytes (W3/25 $\left.5^{\text {low }}\right), \mathrm{CD} 45 \mathrm{RC}^{+} \mathrm{CD} 4^{+} \mathrm{T}$ cells (W3/25 $5^{\text {high }}$,

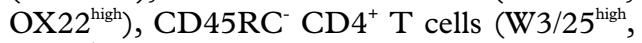
$\left.\mathrm{OX} 22^{\text {low }}\right)$. Interleukin 2 receptor expression was determined by a single staining technique using OX39, and goat antimouse polyclonal antibodies coupled to FITC. MAb and isotype matched irrelevant antibodies served as controls. Only viable cells as determined by forward and side scatter characteristics were analysed using a FACScan flow cytometer. Absolute subset numbers were calculated using leucocyte counts, differential blood count, and percentage of subsets as determined by flow cytometry.

\section{STATISTICAL ANALYSIS}

All measurements are shown as mean (SEM) unless otherwise stated. To compare two different groups the Mann-Whitney U test was applied. Differences were considered significant if the $\mathrm{p}$ value was $\leqslant 0.05$. Three group comparison was done by the Kruskal-Wallis test followed by pairwise comparison using the Mann-Whitney U test if the Kruskal-Wallis test was significant (significance level $\leqslant 0.05$ ). For comparison of radiographic scores (comparison of seven groups) first the Kruskal-Wallis test was performed and, if significant, the multiple comparison procedure by Tukey-Kramer, which controls experiment wise error rate. ${ }^{14}$

\section{Results}

SUPPRESSION OF ESTABLISHED AA BY COMBINED TREATMENT WITH THE ANTI-CD2 MAB OX34 AND DEXAMETHASONE

We have previously shown that OX34 treatment has an anti-inflammatory effect on established AA. ${ }^{10}$ However, this treatment does not affect bone destruction as demonstrated by similar radiographic scores for OX34 or control $\mathrm{mAb}$ treated $\mathrm{AA}$ rats (fig 1). In an attempt to achieve joint protection we combined OX34 treatment with a one day dexamethasone pulse. Indeed, a strong reduction of the AS was found in the OX34 plus dexamethasone treated group compared with dexamethsone plus control $\mathrm{mAb}$ treated group (each group $\mathrm{n}=5, \mathrm{p}<0.05$ from day 17 to day 27)(fig 2). However, the reduction of bone destruction was not significant when compared with AA rats receiving dexamethasone plus control $\mathrm{mAb}$ (fig 1).

To further improve the effect on bone destruction we next modified the treatment protocol by giving dexamethasone on two consecutive days and OX34 starting just after the onset of arthritis-that is, day 12 after AA induction. This modification resulted in almost complete joint protection (mean radiographic score 0.25 versus $3.75, p<0.05$ ) (fig 1 ) and significant clinical improvement (AS and hindpaw thickness) when compared with a control group receiving dexamethasone over two days plus control $\mathrm{mAb}$ starting on day 12 (fig $3 \mathrm{~A}$ and B). When OX34 plus dexamethasone was started on day 18 (same regimen as above) the reduction of AS and hindpaw thickness was also significant compared with dexamethasone 


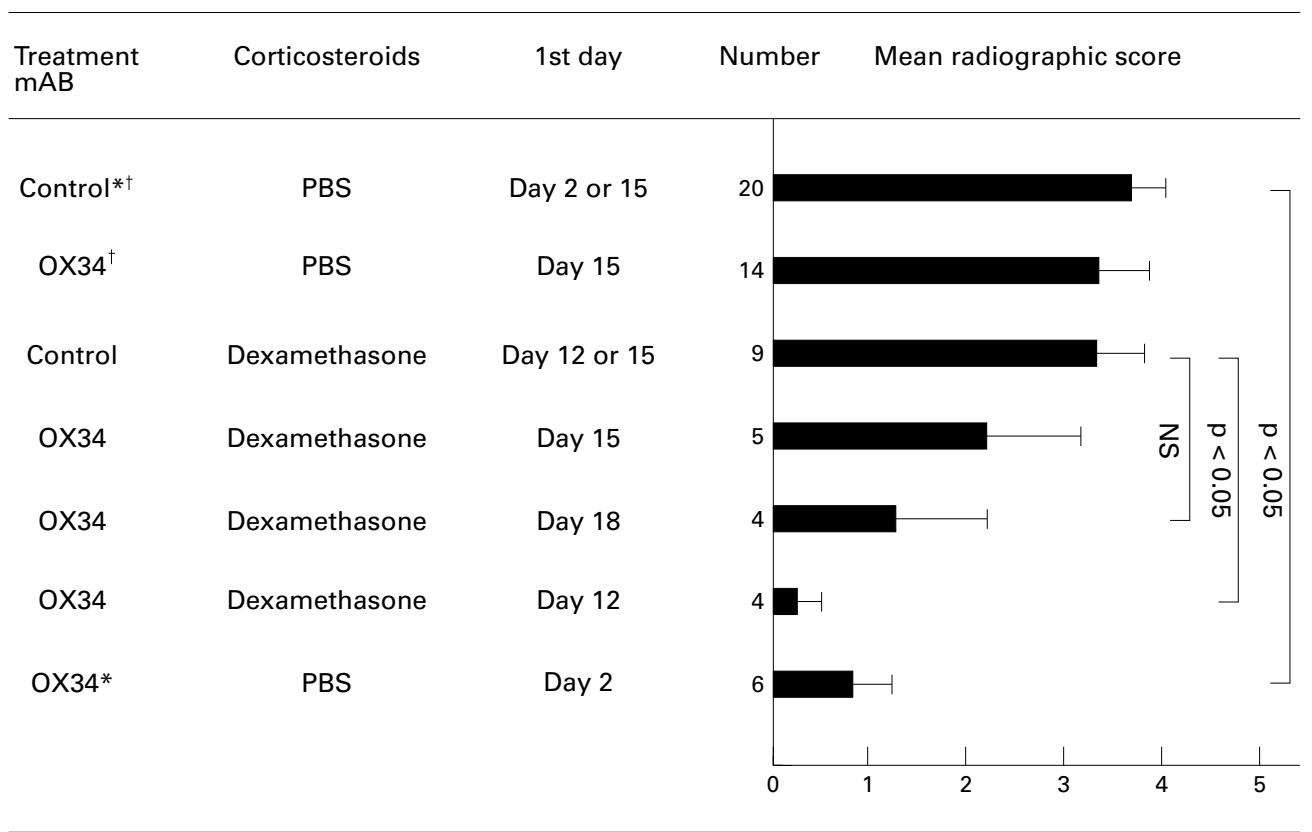

Figure 1 Influence of dexamethasone or OX34 treatment, or both, on radiographic bone destruction of $A A$ rats. Indicated is the mean radiographic score of both hindpaws, the SEM for each treatment group, and the levels of significance. Radiographic scores of two groups of 14 rats receiving either OX34 or control mAb are included from a previous study (Hoffmann et al, unpublished data). All $\mathrm{mAb}$ treatments were started with $2 \mathrm{mg}$ followed by $1 \mathrm{mg}$ intraperitoneally per injection day, $m A b$ were given over three consecutive days unless stated otherwise; dexamethasone was given intraperitoneally at $1 \mathrm{mg} / \mathrm{kg}$ body weight either for two consecutive days starting on day 12 or 18 or once on day 15 . * = $m A b$ given two days and one day before induction of $A A$ and on the day of induction. $+=m A b$ given on day 15, 17,20 , and 23 after induction of $A A$.

plus control mAb starting on day $12(\mathrm{p}<0.05)$, however the reduction in bone destruction was not (mean radiographic score 1.25 versus 3.75, $\mathrm{p}=0.08)$. As no radiographic difference was found between AA rats treated with dexamethasone plus control $\mathrm{mAb}$ on day 12 or day 15 these animals were pooled in fig 1 .

OX34 PLUS DEXAMETHASONE TREATMENT REDUCES CD $4^{+} \mathrm{T}$ CELLS AND ACTIVATED T CELLS IN PERIPHERAL BLOOD

OX34 treatment without dexamethasone was previously found to deplete $\mathrm{CD} 4^{+}$but not $\mathrm{CD}^{+} \mathrm{T}$ cells. ${ }^{10} \mathrm{~A}$ similar effect was found after treatment with OX34 plus dexamethasone starting on day 12 . Therefore, flow cytometry

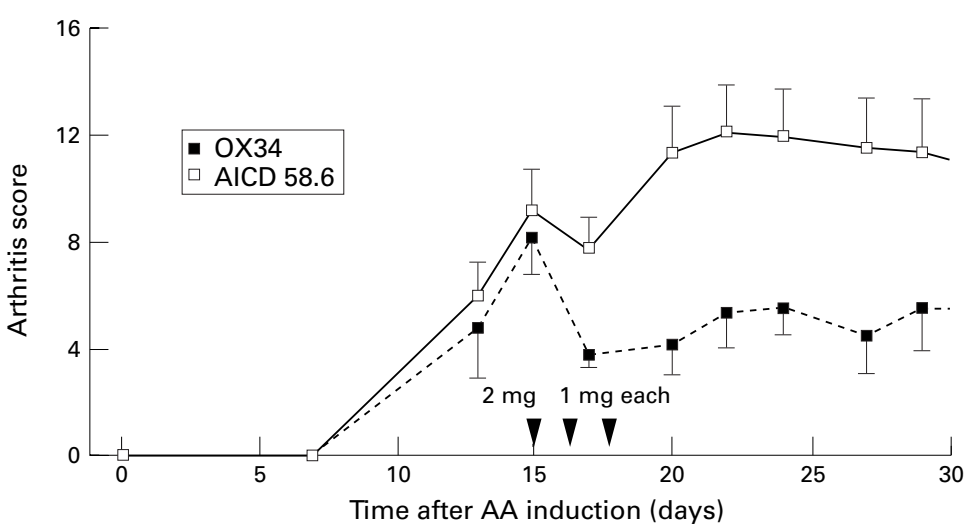

Figure 2 Amelioration of established $A A$ by dexamethasone plus OX34 mAb therapy. Ten animals with established $A A$ were randomised to intraperitoneal injections of $O X 34(n=$ $5)$ or istotype matched control $m A b(A I C D 58.6, n=5)$ over three consecutive days starting with a loading dose of $2 \mathrm{mg}$ followed by $1 \mathrm{mg}$ each at indicated time points (arrows). Dexamethasone was given intraperitoneally on day 15 at a dose of $1 \mathrm{mg} / \mathrm{kg}$ body weight. Arthritis score was measured by a blinded investigator at indicated time points. Shown are means (SEM), arrows indicate mAb injections. at the end of the study (day 29) showed depletion of $\mathrm{CD}^{+}$, but not NK cells and $\mathrm{CD} 8^{+} \mathrm{T}$ cells (table 1). Dexamethasone and control $\mathrm{mAb}$ had no significant effect on $\mathrm{CD} 4^{+} \mathrm{T}$ cell concentrations (data not shown). The following leucocyte subsets were found to be unchanged: neutrophils (control: 4847 (511)/ $\mu \mathrm{l}$; OX34: $5766(896) / \mu \mathrm{l}$ ), monocytes (control: $781(60) / \mu \mathrm{l}$; OX34: $644(120) / \mu \mathrm{l})$, and B

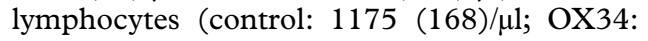
$1523(141) / \mu \mathrm{l})$. No differences were seen between early and late OX34 treatment (data not shown).

When looking at activation markers after combined dexamethasone plus OX34 therapy starting on day 12, the concentrations of CD45 RC' $\mathrm{CD}^{+}$('memory') $\mathrm{T}$ cells and IL2 ${ }^{+}$ PMNC were significantly reduced (table 1). Different starting points of OX34 treatment gave similar results when looking at these leucocyte subsets (data not shown). Reduction of numbers of $\mathrm{CD} 4^{+} \mathrm{T}$ cells, 'memory' $\mathrm{T}$ cells, or $\mathrm{IL}_{2} \mathrm{R}^{+} \mathrm{PMNC}$ therefore did not correlate with the degree of bone protection (data not shown).

PREVENTION OF AA BY TREATMENT WITH THE ANTI-CD2 MAB OX34

As early dexamethasone plus OX34 mAb treatment suppressed the perpetuation of AA we asked next whether OX34 alone might inhibit the initiation of AA. Twelve female rats received blindly either OX34 or isotype matched control mAb starting two days before AA induction. While all animals receiving the control $\mathrm{mAb}$ developed severe polyarthritis by day 13 only two of six rats that had received OX34 mAb had mild arthritis on day 13 (fig 

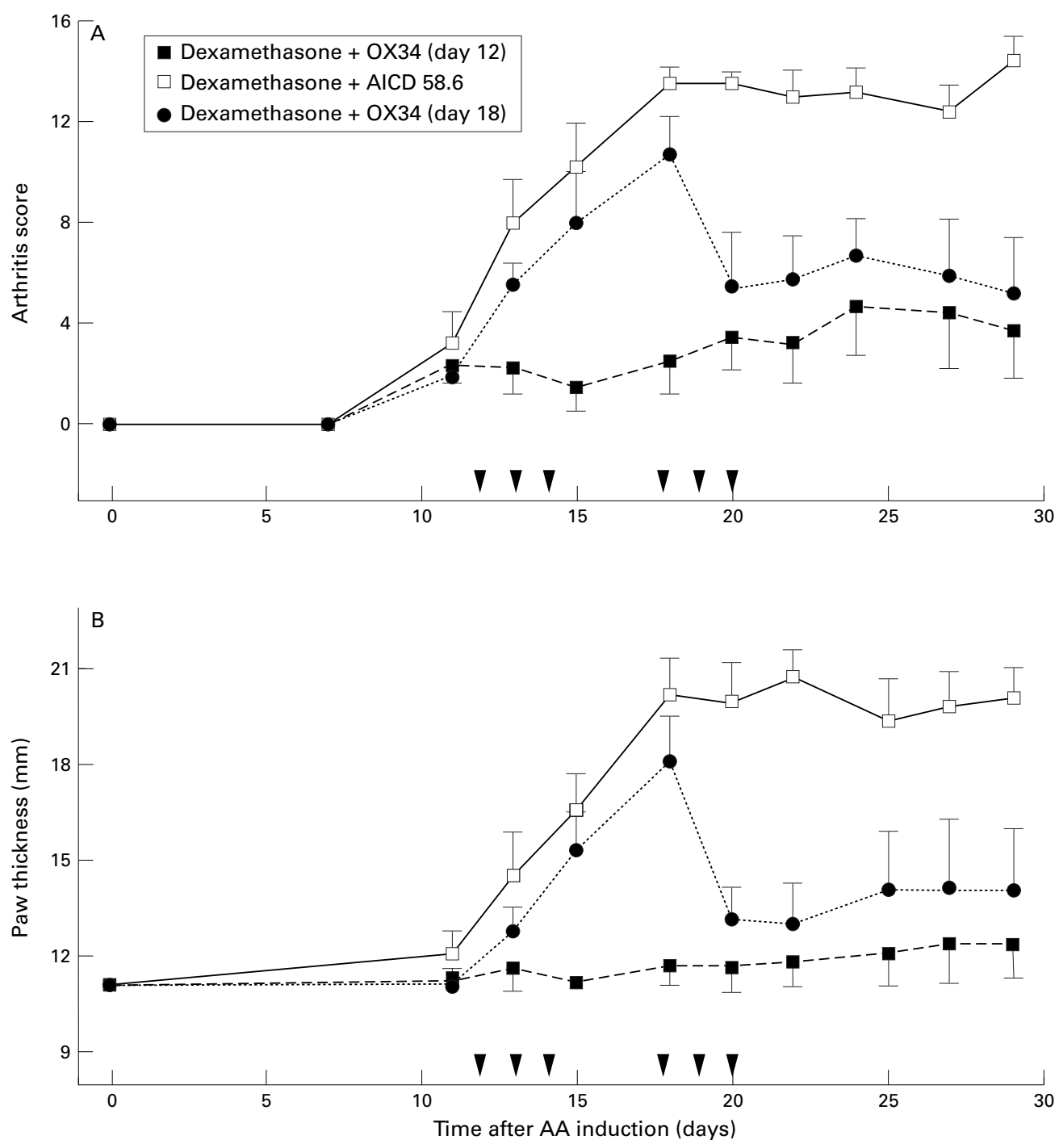

Figure 3 Marked suppression of established AA by early, repeated OX34 mAb injections plus a dexamethasone pulse over two days. Sixteen rats were injected with FCA and 12 rats developed $A A$ by day $12(A S \geqslant 2)$. These were randomised into three groups, four animals each, and received blindly either dexamethasone plus OX34 starting on day $12(n=4)$, dexamethasone plus control mAb (AICD 58.6) starting on day $12(n=4)$, or dexamethasone plus OX34 starting on day $18(n=4)$. PBS was given on those days when no $m A b$ was injected (for example, day 12 to 14 for dexamethasone plus OX34). Dexamethasone diluted in PBS was given at a concentration of $1 \mathrm{mg} / \mathrm{kg}$ body weight on two consecutive days, $m A b s$ were injected for three consecutive days starting with $2 \mathrm{mg}$ followed by $1 \mathrm{mg}$ per day. Arthritis score $(A)$ and hindpaw thickness (B) were measured by a blinded investigator at indicated time points. Symbols and labelling as in figure 2.

4A). Over the whole observation period the highest mean AS of the OX34 treated group was 2.2 compared with 12.8 in the control group. Similarly, hind paw thickness was significantly reduced and body weight increased in the OX34 treated group in comparison with the control group (fig $4 \mathrm{~B}$ and $4 \mathrm{C}$ ). In addition, OX34 treatment drastically reduced bone destruction as judged by hind paw radiography on day 31 (fig 1 ). No difference was found between animals receiving control $\mathrm{mAb}$ before AA induction or on day 15 after AA induction and were therefore pooled in figure 1 .

Table 1 Effect of OX34 and dexamethasone administration on peripheral blood leucocyte subsets on day 29

\begin{tabular}{|c|c|c|c|}
\hline & $\begin{array}{l}\text { OX34 + dexamethasone } \\
(\text { mean }(S E M))\end{array}$ & $\begin{array}{l}\text { Control mAb }+ \text { dexamethasone } \\
(\text { mean }(S E M))\end{array}$ & $\begin{array}{l}\text { Difference } \\
\text { ( } p \text { value) }\end{array}$ \\
\hline Peripheral blood mononuclear cells & $4370(365)$ & $7345(583)$ & $<0.01$ \\
\hline $\mathrm{CD} 4^{+} \mathrm{T}$ cells $\left(\mathrm{W} 3 / 25^{\text {high }}\right)$ & $439(82)$ & $3072(360)$ & $<0.001$ \\
\hline $\mathrm{CD}^{+} \mathrm{T}$ cells $\left(\mathrm{R} 73^{+} / \mathrm{OX}^{+}\right)$ & $931(70)$ & $982(76)$ & NS \\
\hline Natural killer cells $\left(\mathrm{R} 73^{-} / \mathrm{OX}^{+}\right)$ & $497(104)$ & $785(35)$ & NS \\
\hline $\mathrm{CD}^{2} 5 \mathrm{RC}^{-} \mathrm{CD} 4^{+} \mathrm{T}$ cells $\left(\mathrm{OX} 22^{\text {low }} / \mathrm{W} 3 / 25^{\mathrm{high}}\right)$ & $270(42)$ & $721(116)$ & $<0.001$ \\
\hline IL2 receptor ${ }^{+}$cells $\left(\mathrm{OX} 39^{+}\right)$ & $46(6)$ & $128(21)$ & $<0.001$ \\
\hline
\end{tabular}

Cell numbers (per $\mu \mathrm{l}$ ) were calculated using differential blood smears, leucocyte counts, and percentage of subsets as determined by double staining and flow cytometry on day 29 after AA induction. The OX 34 + dexamethasone group received the OX $34 \mathrm{mAb}$ at a loading dose of $2 \mathrm{mg}$ followed by $1 \mathrm{mg}$ for the subsequent two days plus dexamethsone $(1 \mathrm{mg} / \mathrm{kg}$ body weight $)$ starting on day 12 . The control group received the isotype matched control mAb instead of OX34. 

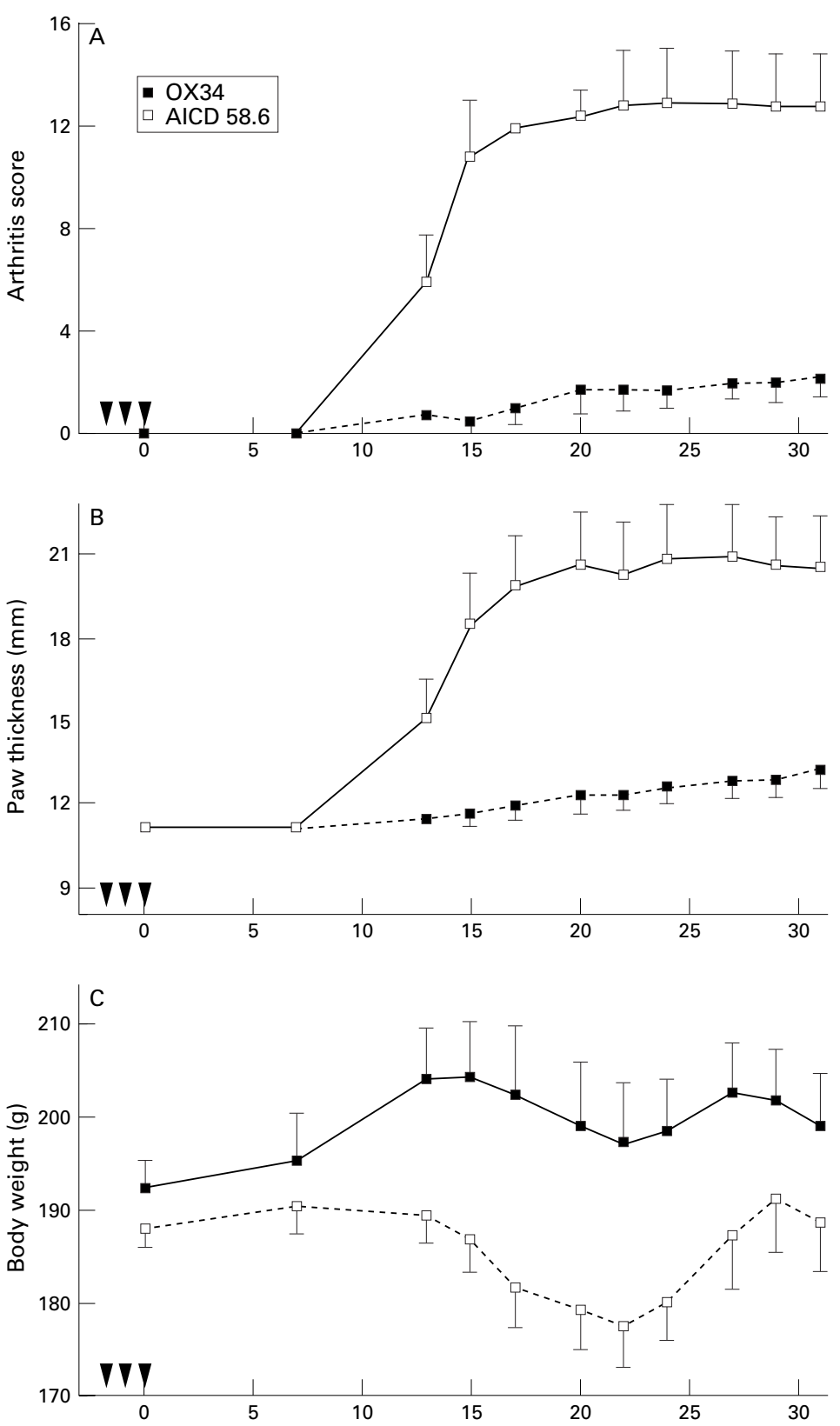

Time after AA induction (days)

Figure 4 Prevention of $A A$ induction by the anti-CD2 $m A b$ OX34. Twelve animals were randomised to intraperitoneal administration of $O X 34(n=6)$ or istotype matched control $m A b(A I C D 58.6, n=6)$ as in figure 3 before $A A$ induction. Arthritis score $(A)$, hind paw thickness (B), and body weight $(C)$ was measured by a blinded investigator at indicated time points. Symbols and labelling as in figure 2.

\section{Discussion}

Three important findings are described in this report: (1) Dexamethasone pulse therapy over two days plus OX34 over three days effectively suppressed synovitis in established AA when used early in the disease process. More importantly, dexamethasone plus early OX34 therapy prevented bone destruction in established AA. (2) In addition to its clinical effectiveness, OX34 plus dexamethasone reduced activated peripheral blood $\mathrm{T}$ cells as assessed by IL 2 receptor and CD45RC expression. (3) The anti-CD2 mAb OX34 almost completely prevents the induction of AA.
Similar to human RA, the development of AA can be devided into three phases starting with the induction phase without evidence of synovitis, followed by early synovitis, and finally late synovitis with progressive joint destruction. Our data suggest that $\mathrm{T}$ cells and $\mathrm{CD} 4^{+} \mathrm{T}$ cells in particular are very important in the initiation phase of $\mathrm{AA}$ as OX34 selectively depletes $\mathrm{CD}^{+} \mathrm{T}$ cells resulting in almost complete prevention of AA formation. This finding confirms the notion that $\mathrm{CD} 4^{+}$ rather than macrophages or fibroblasts are of primary importance for the induction of AA. Still, some groups regard macrophages and pannocytes as initiating cell type in chronic forms of arthritis. ${ }^{15}{ }^{16}$ However, several lines of evidence suggest that $\mathrm{T}$ cells, and $\mathrm{CD} 4^{+} \mathrm{T}$ cell in particular, are the most important cell type in the initiation phase of chronic forms of arthritis. $\mathrm{CD}^{+} \mathrm{T}$ cells are among the first cells to reach inflamed joints. ${ }^{6}$ Neonatal thymectomy or depletion by $\mathrm{mAb}$ therapy of $\mathrm{T}$ cells or of $\mathrm{CD}^{+} \mathrm{T}$ cells prevents $\mathrm{AA}$ induction in Lewis rats. ${ }^{417} 18$ Therefore, the driving force in the initiation phase of AA, and probably other chronic forms of arthritis, seems to be the $\mathrm{CD}^{+} \mathrm{T}$ cell subset.

In the second phase of AA, early synovitis, the joint becomes infiltrated by macrophages and neutrophils. Accordingly, depleting T cells or even $\mathrm{CD}^{+} \mathrm{T}$ cells by mAb therapy only ameliorates AA for a short period of time - that is, at most one week. ${ }^{419}$ In contrast, amelioration of established AA by OX34 and dexamethasone lasts for at least 2.5 weeks when given at an early stage. As dexamethasone is known to inhibit activation and immigration of monocytes and neutrophils ${ }^{5021}$ it can be speculated that dexamethasone over two days blocks macrophage and neutrophil infiltration while OX 34 targets $T$ cells. These $T$ cells seem to be the driving force in this phase of inflammation because dexamethasone over only two days with the control $\mathrm{mAb}$ had no significant effect on AA. This hypothesis is supported by data from Issekutz et al showing that dexamethasone inhibits migration of monocytes and neutrophils but not $\mathrm{T}$ lymphocytes to inflamed joints. ${ }^{5}$ Attacking both, $\mathrm{T}$ cells and inflammatory mediators, has previously been reported to be highly effective in established collagen arthritis using anti-TNF $\alpha$ and anti-CD4 mAb. ${ }^{11}$ Similarly, our approach to target CD $4^{+}$ $\mathrm{T}$ cells by OX34 and macrophages/neutrophils by dexamethasone effectively suppressed established AA leading to joint protection. As a result of this immunotherapy peripheral activated $T$ cells were found to be reduced.

The last phase of AA is late synovitis, which is characterised by progressive joint destruction. Although affected joints are infiltrated by mononuclear cells and predominantly $\mathrm{CD} 4^{+} \mathrm{T}$ cells this phase is dominated by activated macrophages, which destroy the cartilage and stimulate fibroblasts and chondrocytes leading to progressive joint destruction and pannus formation. Therefore, important damage has already occurred in late synovitis. This is reflected in our experiments by some bone destruction when dexamethasone plus OX34 is 
given at a late stage of disease. Still, the anti-inflammatory effect of this late treatment was almost equivalent to early treatment suggesting that $\mathrm{T}$ cells also participated in the maintenance of synovitis during this phase of disease. The anti-inflammatory effect and the albeit non-significant reduction of bone destruction by the late OX34 plus dexamethasone treatment underline, despite the small sample size of four rats per group, the importance of attacking both $\mathrm{T}$ cells as the driving force and macrophages plus neutrophils as the effector cells even in late AA. As joint protection plus suppression of synovitis are the ultimate goals of a better RA treatment than the currently available DMARDs future studies have to investigate CD2 directed immunotherapies in human RA.

Different mechanisms might be responsible for the clinical effects of OX34 therapy. Certainly the most obvious effect of the OX34 therapy is the depletion of $\mathrm{CD} 4^{+} \mathrm{T}$ cells but not $\mathrm{CD}^{+} \mathrm{T}$ cells. This depletion might explain why OX34 prevents the induction of AA. Secondly, OX34 was shown to interfere with $\mathrm{T}$ cell activation by inhibition of IL2 secretion, a finding that has also been reported for anti-CD2 $\mathrm{mAb}$ in the human system..$^{23}$ Thirdly, OX34 inhibits the CD2/CD48 interaction by two mechanisms: (1) OX34 blocks the CD2/CD48 interaction directly by binding to the CD48 binding epitope on the CD2 molecule. ${ }^{24}$ (2) OX34 leads to longlasting downmodulation of the CD2 molecule on $\mathrm{CD} 4^{+} \mathrm{T}$ cells. ${ }^{10}$ As multiple immune functions such as macrophage activation, $B$ cell differentiation, and $\mathrm{T}$ cell activation are mediated via the CD2/CD48 interaction ${ }^{25-28}$ blocking this interaction might well explain the antiinflammatory effect of this mAb. To this end, treatment with OX34 not only suppresses AA but also induces tolerance in a rat heart transplant model, ${ }^{22}$ prevents transfer of diabetes, ${ }^{29}$ and suppresses established experimental autoimmune encephalomyelitis. ${ }^{30}$

In summary, the anti-CD2 mAb OX34 prevents AA induction emphasising the importance of $\mathrm{T}$ cells, particularly $\mathrm{CD} 4^{+} \mathrm{T}$ cells, in the induction phase of AA. In addition, combined OX34 plus dexamethasone treatment suppresses established AA and, at least when used in early synovitis, prevents joint destruction. Therefore, OX34 plus dexamethasone interferes with the maintenance of arthritis showing that $\mathrm{T}$ cells and mainly $\mathrm{CD}^{+} \mathrm{T}$ cells perpetuate the arthritic process. Further studies are needed to investigate the mechanism of action of OX34, the long term efficacy of this treatment, and to evaluate whether a CD2 directed immunotherapy might be suitable for human RA.

This study was supported by SFB grant 244-A7 to JW, DFG-grant Ho $1561 / 1-2$ to JCH, and by an award to JCH from the Kurt-Eberhard Bode foundation. The authors thank $\mathrm{K}$ Bankes-John, I Dressendörfer, and F Weidner for technical assistance with flow cytometry, differential blood counts, and immunohistology. Also, we are grateful to T Krüger for excellent animal care and C Falkenstein for help in performing radiographs. We kindly acknowledge the help of J König in performing statistical analysis.
Some of these results were presented at the Annual meeting of the Deutsche Gesellschaft für Immunologie in Hamburg, Germany, 1996.

1 Crofford LJ, Wilder RL. Arthritis and autoimmunity in animals. In: McCarty DJ, Koopman WJ, eds. Arthritis and allied conditions. Philadelphia: Lea \& Febiger, 1993: 525-41

2 Taurog JD, Argentieri DC, McReynolds RA. Adjuvant arthritis. Methods Enzymol 1988;162:339-55.

3 Issekutz AC, Meager A, Otterness I, Issekutz TB. The role of tumour necrosis factor-alpha and IL-1 in polymorphonuclear leucocyte and $\mathrm{T}$ lymphocyte recruitment to joint inflammation in adjuvant arthritis. Clin Exp Immunol 1994;97:26-32.

4 Yoshino S, Schlipkoter E, Kinne R, Hunig T, Emmrich F. Suppression and prevention of adjuvant arthritis in rats by a monoclonal antibody to the alpha/beta $\mathrm{T}$ cell receptor. Eur J Immunol 1990;20:2805-8.

5 Issekutz AC, Issekutz TB. Quantitation and kinetics of polymorphonuclear leukocyte and lymphocyte accumulation in oints during adjuvant arthritis in the rat. Lab Invest 1991; 64:656-63.

6 Halloran MM, Szekanecz Z, Barquin N, Haines GK, Koch A E. Cellular adhesion molecules in rat adjuvant arthritis. Arthritis Rheum 1996;39:810-9.

7 Alarcon GS, Lopez Mendez A, Walter J, Beerbooms AM, Russell AS, Furst DE, et al. Radiographic evidence of disease progression in methotrexate treated and nonmethotrexate disease modifying antirheumatic drug treated rheumatoid arthritis patients: a meta-analysis. J Rheumatol 1992;19:1868-73.

8 Lopez Mendez A, Daniel WW, Reading JC, Ward JR, Alarcon GS. Radiographic assessment of disease progression in rheumatoid arthritis patients enrolled in the cooperative systematic studies of the rheumatic diseases program randomized clinical trial of methotrexate, auranofin, or a combination of the two. Arthritis Rheum 1993;36:1364-9.

9 Weinblatt ME, Polisson R, Blotner SD, Sosman JL, Aliabadi $\mathrm{P}$, Baker $\mathrm{N}$, et al. The effects of drug therapy on radiographic progression of rheumatoid arthritis. Results of 36-week randomized trial comparing methotrexate and auranofin. Arthritis Rheum 1993;36:613-9.

10 Hoffmann JC, Herklotz C, Zeidler H, Bayer B, Westermann J. Anti-CD2 (OX34) MoAb treatment of adjuvant arthritic rats: attenuation of established arthritis, selective depletion of CD4+ T cells, and CD2 downmodulation. Clin Exp Immunol 1997;110:63-71.

11 Williams RO, Mason LJ, Feldmann M, Maini RN. Synergy between anti-CD4 and anti-tumor necrosis factor in the amelioration of established collagen-induced arthritis. Proc Natl Acad Sci USA 1994;91:2762-6.

12 Peacock DJ, Banquerigo ML, Brahn E. Angiogenesis inhibition suppresses collagen arthritis. J Exp Med 1992;175: 1135-8.

13 Westermann J, Nagahori Y, Walter S, Heerwagen C, Miyasaka M, Pabst R. B and T lymphocyte subsets enter peripheral lymph nodes and Peyer's patches without preference in vivo: no correlation occurs between their localization in different types of high endothelial venules and the expression of CD44, VLA-4, LFA-1, ICAM-1, CD2 or L-selectin. Eur J Immunol 1994;24:2312-6.

14 Hocherg Y, Tamhane AC. Multiple comparison procedures. New York: John Wiley, 1987 .

15 Meacock SC, Brandon DR, Billingham ME. Arthritis in Lewis rats induced by the non-immunogenic adjuvant CP20961: an immunohistochemical analysis of the developing disease. Ann Rheum Dis 1994;53:653-8.

16 Zvaifler NJ, Firestein GS. Pannus and pannocytes. Alternative models of joint destruction in rheumatoid arthritis. Arthritis Rheum 1994;37:783-9.

17 Kohashi O, Pearson CM, Tamaoki N, et al. Role of thymus for N-acetyl muramyl-L-alanyl-D-isoglutamine-induced polyarthritis and granuloma formation in euthymic and athymic nude rats or in neonatally thymectomized rats. Infect Immun 1981;31:758-66.

18 Pelegri C, Paz Morante M, Castellote C, Castell M, Franch A. Administration of a nondepleting anti-CD4 monoclonal rechallenge: pallel administration of a depleting antirechallenge: parallel administration of a depleting antiCD8 monoclonal antibody (OX8) does not modify the
effect of W3/25. Cell Immunol 1995;165:177-82.

19 Pelegri C, Morante MP, Castellote C, Franch A, Castell M. Treatment with an anti-CD4 monoclonal antibody Treatment with an anti-CD4 monoclonal antibody
strongly ameliorates established rat adjuvant arthritis. Clin strongly ameliorates established

20 Sternberg EM, Wilder RL. Corticosteroids. In: McCarty DJ, Koopman WJ, eds. Arthritis and allied conditions. Philadelphia: Lea \& Febiger, 1993: 665-82.

21 Axelrod L. Glucocorticoids. In: Kelley WN, Harris ED, Ruddy S, Sledge CB, eds. Textbook of rheumatology. Philadelphia: Saunders, 1993: 779-96.

22 Hirahara $H$, Tsuchida $M$, Watanabe $T$, Hanawa $H$, Matsumoto Y, Abo T, et al. Long-term survival of cardiac allografts in rats treated before and after surgery with monoclonal antibody to CD2. Transplantation 1995; 59:85-90

23 Reed JC, Tadmori W, Kamoun M, Koretzky G, Nowell PC. Suppression of interleukin 2 receptor acquisition by monoclonal antibodies recognizing the $50 \mathrm{KD}$ protein associated clonal antibodies recognizing the $50 \mathrm{KD}$ protein associated
with the sheep erythrocyte receptor on human $\mathrm{T}$ lymphocytes. J Immunol 1985;134:1631-9. 
24 van der Merwe PA, McPherson DC, Brown MH, Barclay AN, Cyster JG, Williams AF, et al. The NH2-terminal domain of rat CD2 binds rat CD48 with a low affinity and binding does not require glycosylation of CD2. Eur J

25 Arvieux J, Jefferies WA, Paterson DJ, Williams AF, Green JR. Monoclonal antibodies against a rat leucocyte antigen block antigen-induced T-cell responses via an effect on accessory cells. Immunology 1986;58:337-42.

26 Seaman WE, Eriksson E, Dobrow R, Imboden JB. Inositol trisphosphate is generated by a rat natural killer cell tumor in response to target cells or to crosslinked monoclona antibody OX-34: possible signaling role for the OX-34 determinant during activation by target cells. Proc Natl Acad Sci USA 1987;84:4239-43.
27 Gückel B, Berek C, Lutz M, Altevogt P, Schirrmacher V, Kyewski BA. Anti-CD2 antibodies induce T cell unresponsiveness in vivo. J Exp Med 1991;174:957-67.

28 Hershkoviz R, Gilat D, Miron S, Mekori YA, Aderka D, Wallach D, et al. Extracellular matrix induces tumour necrosis factor-alpha secretion by an interaction between resting rat CD4+ $\mathrm{T}$ cells and macrophages. Immunology 1993;78:50-7.

29 Barlow AK, Like AA. Anti-CD2 monoclonal antibodies prevent spontaneous and adoptive transfer of diabetes in the BB/Wor rat. Am J Pathol 1992;141:1043-51.

30 Jung S, Toyka K, Hartung HP. Suppression of experimental autoimmune encephalomyelitis in Lewis rats by antibodies against CD2. Eur J Immunol 1995;25:1391-8. 